\section{Media Pembelajaran}
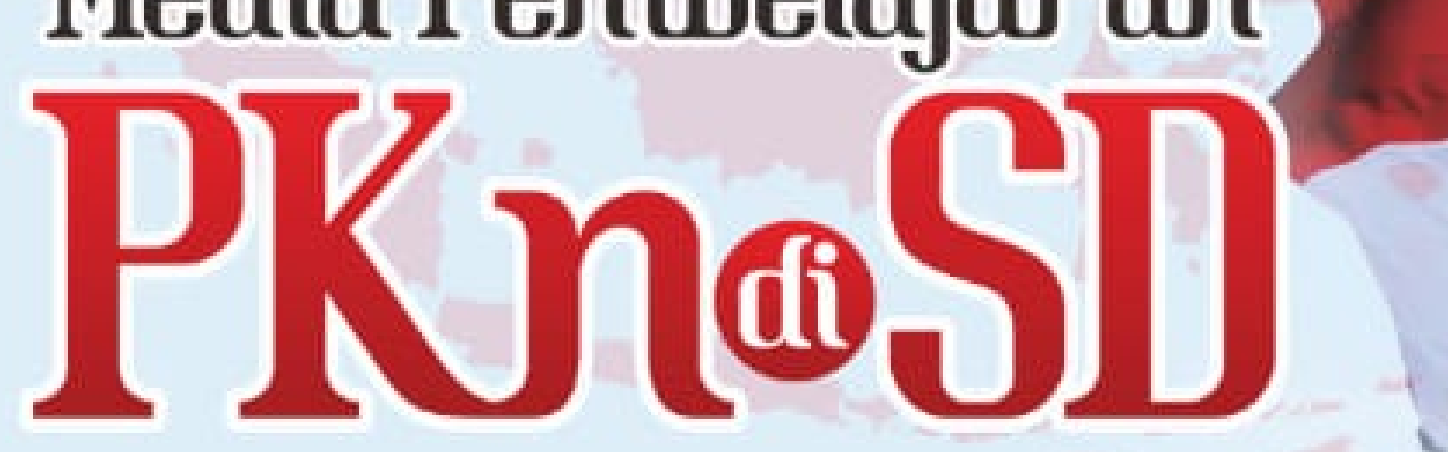

Buku Media Pembelajaran PKn di SD merupakan buku yang berisi tentang konsep dasar Media Pembelajaran PKn dan contoh-contoh media pembelajaran PKn yang keretif dan inovatif yang dapat diterapkan pada peserta didik khususnya di Sekolah Dasar. Buku ini dibuat harapannya dapat membantu pendidik dalam mencari refrensi tentang media pembelajaran PKn di SD, karena di dalam buku ini tidak mengkaji tentang konsep media pembelajaran saja tetapi dilengkapi dengan deskripsi media pembelajaran, materi pembelajaran, bahan dan alat, langkah-langkah pembuatan media pembelajaran dan dilengakpi dengan cara penggunaan media tersebut dalam pembelajaran. Dengan adanya pemaparan yang lengkap diharapkan dapat membantu pembaca yang ingin mencoba membuat dan menerapkan media pembelajaran PKn diSD.

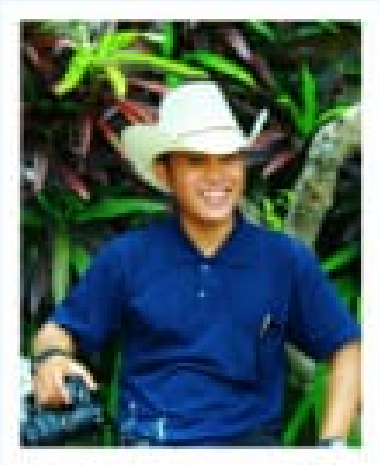

Aji Heru Muslim, M.Pd, Lahir di Desa Kendaga Kecamatan Banjarmangu, Kabupaten Banjarnegara, 06 Mei 1989, Anak ke satu dari tiga bersaudara dari sebuah keluarga petani. Pendidikan SDSLTP-SMK ditamatkan di Kabupaten Banjarengara. Pendidikan S1 di tempuh di Universitas Muhammadiyah Purwokerto (UMP) dengan jurusan PGSD. Pendidikan S2 ditempuh di Universitas Negeri Semarang (UNNES) dengan jurusan Pendidikan Dasar Konsentrasi PGSD. Penulis saat ini mengabdikan diri sebagai Dosen PGSD di Universitas Muhammadiyah Purwokerto. Pengalaman menjabat struktural diantara lain sebagai kepala Laboratorium Kelas Model PGSD tahun 2012-2013, Koordinator BIPA UMP tahun 2014-2016, Sekertaris Prodi PGSD UMP masa jabatan 2016-2020, dan Sekertaris Program Pendidikan Profesi Guru (PPG) masa jabatan 2020-2024. Selain aktif di akademik kampus penulis ikut aktif dalam organisasi lainya meliputi Pengurus ISPI Kab.Banyumas masa bakti 2014-2019, Pengurus APPBIPA Jawa Tengah masa bakti 2019-2023, Pengurus Daerah ISPI Jawa Tengah masa bakti 2016-2021, dan Pengurus Asosiasi PGSD LPTK PTM masa bakti 2018-2022. Beberapa karya ilmiah diterbitkan berupa buku diantaranya Buku Startegi Belajar Mengajar di Sekolah Dasar, dan Buku Pendidikan Anak Berkebutuhan Khusus.

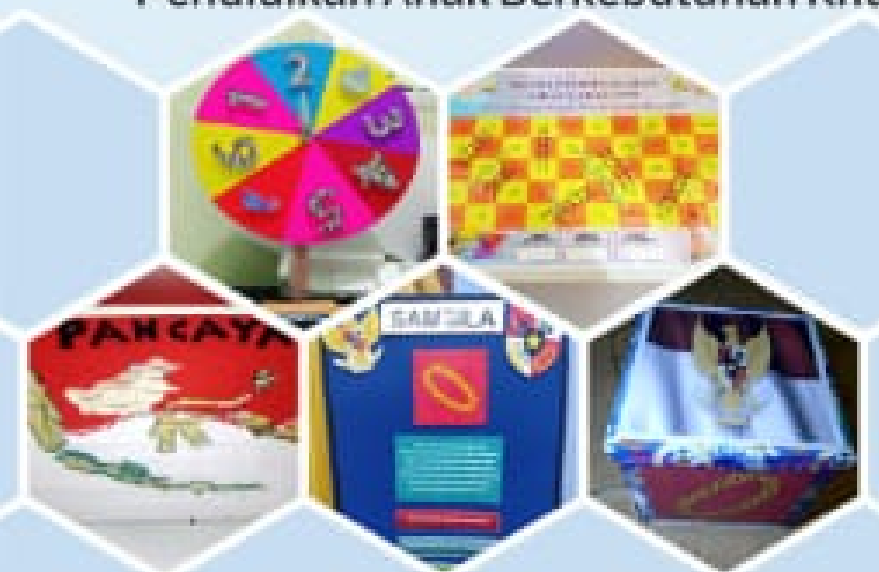

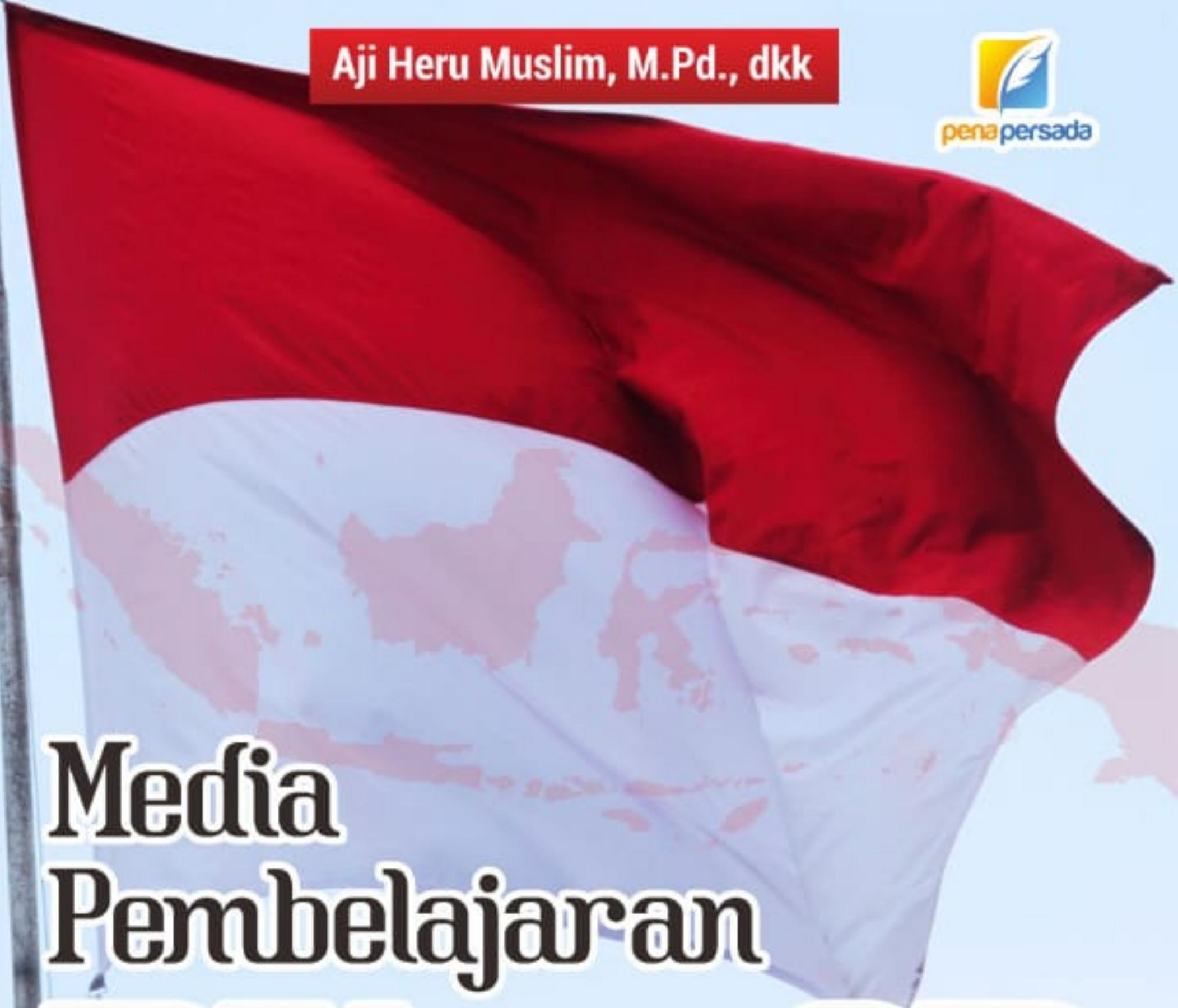

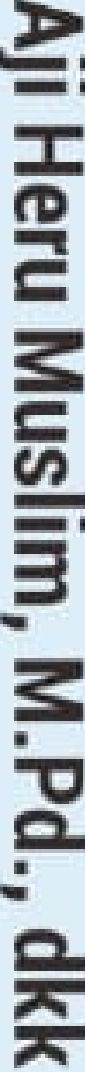

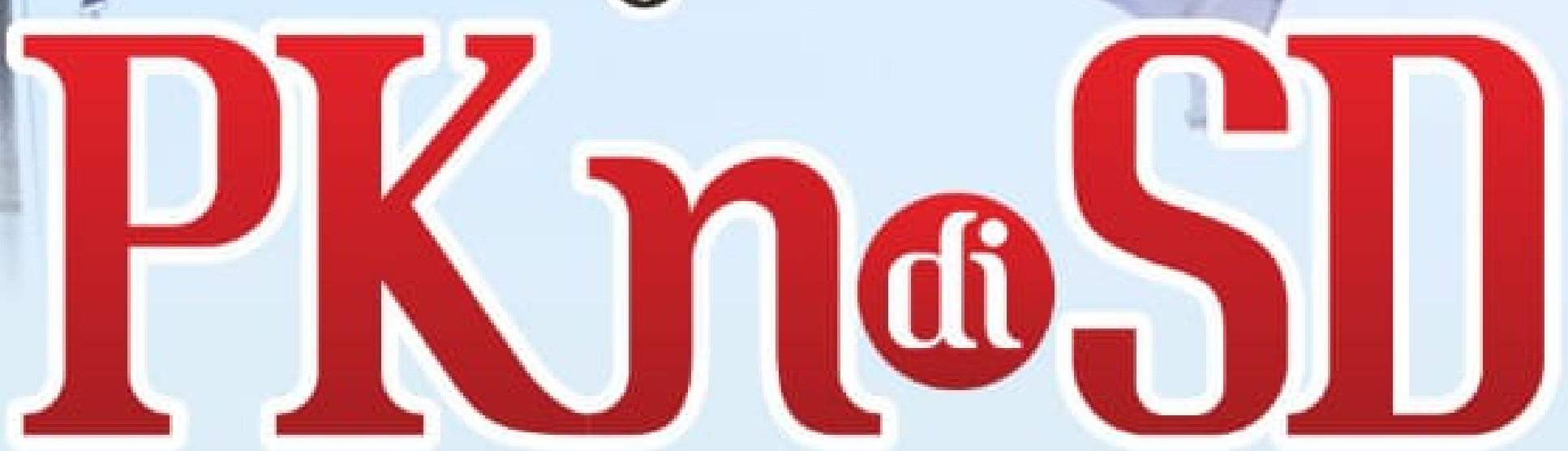

Kata Pengantar :

Irawati, SE. (Kepala Dinas Pendidikan Kab. Banyumas)

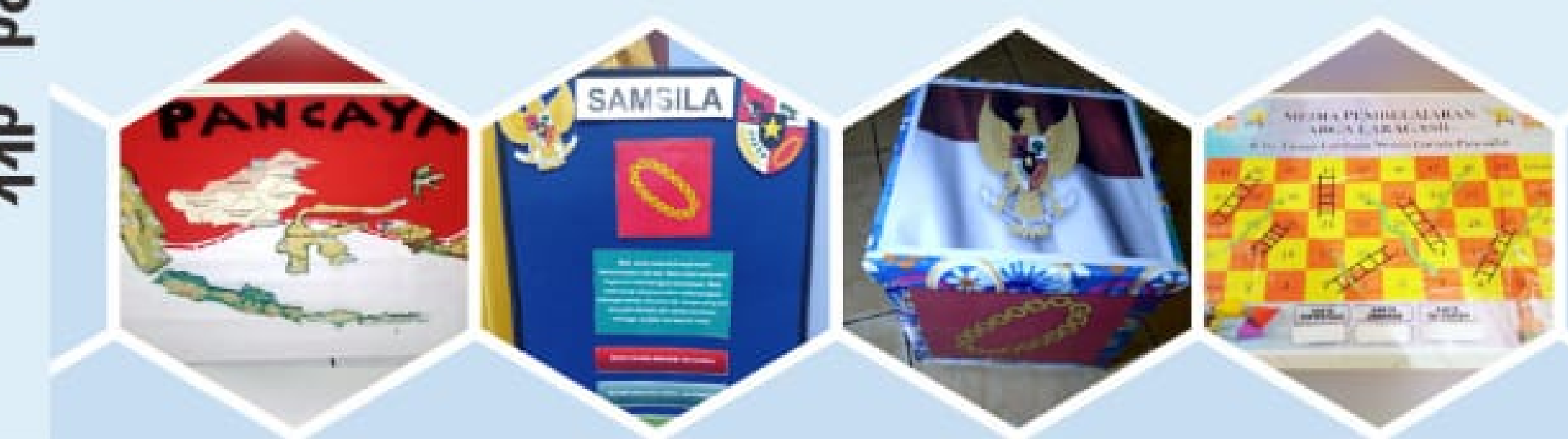




\section{Media Pembelajaran PKn di SD}

Aji Heru Muslim, M.Pd. dkk

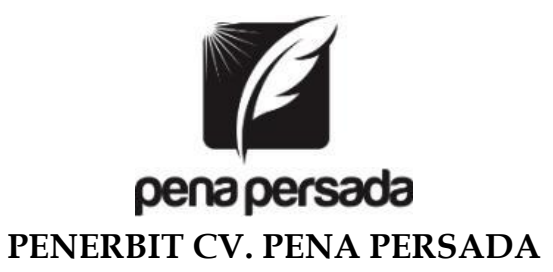




\title{
Media Pembelajaran PKn di SD
}

\author{
Penulis : \\ Aji Heru Muslim, M.Pd. dkk \\ ISBN : 978-623-7699-79-8 \\ Design Cover : \\ Retnani Nur Briliant \\ Layout : \\ Nisa Falahia \\ Penerbit CV. Pena Persada \\ Redaksi : \\ Jawa Tengah \\ Email : penerbit.penapersada@gmail.com \\ Website : penapersada.com \\ Phone : (0281) 7771388
}

Jl. Gerilya No. 292 Purwokerto Selatan, Kab. Banyumas

\section{Anggota IKAPI}

All right reserved

Cetakan pertama : 2020

Hak cipta dilindungi oleh undang-undang. Dilarang memperbanyak karya tulis ini dalam bentuk apapun tanpa ijin penerbit. 


\section{KATA PENGANTAR \\ Irawati, SE. \\ (Kepala Dinas Pendidikan Kabupaten Banyumas)}

Buku yang berjudul "Media Pembelajaran PKn di SD" ini merupakan buku sederhana yang bisa dijadikan sebagai bahan referensi, pegangan atau pedoman bagi pendidik (guru) dalam melaksanakan pembelajaran PKn di sekolah dasar. Didalam Buku Media Pembelajaran PKn di SD penulis menjelaskan terkait dengan konsep dasar Media Pembelajaran PKn dan contohcontoh media pembelajaran PKn yang keretif dan inovatif yang dapat diterapkan pada pembelajaran khususnya di Sekolah Dasar.

Buku ini tidak hanya dilengkapi dengan pengertian konsep media pembelajaran PKn saja tetapi dilengkapi dengan deskripsi media pembelajaran, materi pembelajaran, bahan dan alat, langkah-langkah pembuatan dan cara penggunaan media pembelajaran tersebut di sekolah dasar. Penyajian topik dalam buku ini memberikan gambaran yang jelas bagi guru untuk mengguanakan media pembelajaran PKn di sekolah dasar.

Dengan demikian buku ini layak untuk diterbitkan dalam rangka memenuhi kebutuhan dari kalangan pendidik dan dapat menyumbangkan khazanah ilmu pengetahuan dan keterampilan serta meningkatkan karakter pendidik, mahasiswa/siswa dan menambah pustaka Indonesia. Selanjutnya saya ucapkan terimakasih dan apresiasi kepada penulis atas sumbang pikirnya menerbitkan buku ini, mudah-mudahan buku ini bermanfaat bagi pendidik, mahasiswa, siswa dan semua pihak di satuan pendidikan.

Banyumas, April 2020

Irawati, SE.

Kepala Dinas Pendidikan Kab. Banyumas 


\section{KATA PENGANTAR}

Dengan memohon rahmat dan ridho kepada Allah SWT, sehingga kami bisa menyelesaikan buku berjudul "Media Pembelajaran PKn di SD" dengan lancar dan dimudahkan dalam segala urusan. Shalawat serta salam semoga senantiasa tercurah kepada junjungan kita Nabi Muhammad SAW, keluarga, sahabat dan para pengikutnya yang setia hingga akhir zaman.

Penulisan buku Media Pembelajaran PKn di SD ini dimaksudkan untuk menambah bahan refrensi dan panduan untuk melaksanaan proses pembelajaran di Sekolah Dasar khususnya pada mata pelajaran PKn di SD. Keberadaan media dalam proses pembelajaran tentu saja akan memberikan banyak manfaat terutama bila media tersebut digunakan sesuai dengan kondisi yang ada. Buku Media Pembelajatan PKn di SD ini akan membahas aterkait dengan konsep dasar media pembelajaran PKn di SD dan Contoh-Contoh Media Pembelajaran PKn di SD.

Terwujudnya buku ini penulis menyampaikan terimakasih kepada pihak-pihak yang sudah mendukung dalam proses pembuatan buku ini. Kepada orang tua, istri dan anak, Kepala Dinas Pendidikan Kabupaten Banyumas, kepada Rektor UM Purwokerto, Dekan FKIP UM Purwokerto, Kaprodi PGSD Um Purwokerto, dan tidak lupa kepada teman-teman penulis yang telah berkontribusi dalam pembuatan buku ini.

Penulis menyadari bahwa buku ini yang berjudul Media Pembelajaran PKn di SD masih banyak kekurangan. Oleh karena itu penulis mengaharapkan masukan dan kritikan yang membangun dari semua pihak untuk perbaikan di masa yang akan datang.

Purwokerto, April 2020

Penulis 


\section{DAFTAR ISI}

KATA PENGANTAR (Kepala Dinas Pendidikan Kabupaten

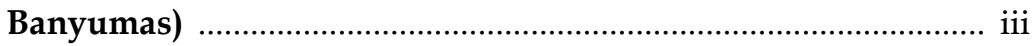

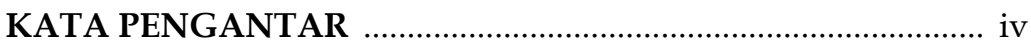

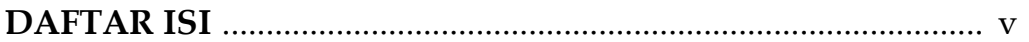

BAGIAN I

KONSEP DASAR MEDIA PEMBELAJARAN PKn

A. Pengertian Media Pembelajaran PKn ..................................... 1

B. Fungsi Media Pembelajaran .................................................... 2

C. Peran Media Pembelajaran PKn SD ....................................... 4

D. Manfaat Media Pembelajaran PKn SD ................................. 8

E. Rancangan Media Pembelajaran PKn Sekolah Dasar ............ 9

\section{BAGIAN II}

\section{CONTOH-CONTOH MEDIA PEMBELAJARAN PKn SD}

1. Kantong Pengetahuan Titis Dias Restanti 13

2. ARGA LARAGASIL (Ular Tangga Lambang Negara Garuda Pancasila) Marshelyna Haraditha .............................. 16

3. Papan Pengetahuan Rina Meliani ........................................ 21

4. SEMAI (Sembilan Nilai) Wulan Fitriani Rosyida.................... 24

5. Spinner Kuis Mardiana Saputri ............................................ 27

6. Papan Budaya Renita Mei Lina ............................................. 31

7. Congklak Tantangan Diah Nirmalawati................................ 34

8. Papan Menjodohkan Tri Yuningsih....................................... 39

9. DADU HAKELI Evy Puput Mulyani.................................... 42

10. PAPEL (Papan Tempel Hak Dan Kewajiban)

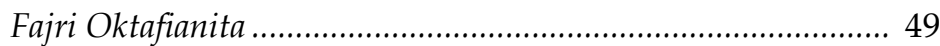

11. DUPAN (Dadu Papan Pancasila) Annisa Isnaeni ................. 52

12. Kantong Doraemon Nurul Kartika ...................................... 57

13. UTANG SOSBUD (Ular Tangga Sosial Budaya)

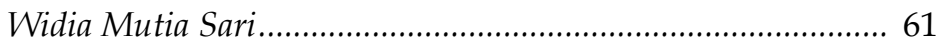

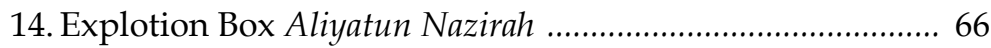

15. Balai Kanca (Bagan Nilai Sikap Pancasila)

Karin Widya Ayuningtyas ...................................................... 71

16. BOKIS (Bola Berkisah) Fadilla Rizki ....................................... 74

17. BIKE (Bingkai Keberagaman) Atun Tri Astuti..................... 77 
18. Papan Gambar Tempel Ani Apriyani.

19. SAMSILA (Simbol Arti Makna Sila Pancasila)

Nadhirotuz Zulfah 88

20. PANCAYA (Papan Tancap Budaya Indonesia)

Nindya Ayu Pratiwi................................................................. 92

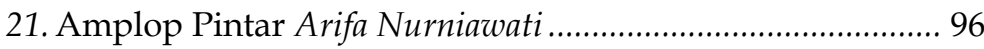

22. Kotak Kebenaran Lita Asri Wahyuni ..................................... 99

23. DABING (Dadu Bintang) Maytri Iscahyani .......................... 103

24. ROLLING BALL Mutiara Fadila Chasna ............................... 109

25. RAINBOWSPIN Meilina Rosiani .......................................... 112

26. KOTETU (Kotak Tempel Bersatu) Dian Eis Prisilawati ....... 115

27. PESSPA (Penerapan Sikap Sesuai Pancasila)

Dewi Retyaningsih................................................................... 120

28. PANCOK (Papan Pencocokan) Bella Wahyuni Wiradhika .... 126

29. PAPIN (Papan Pintar) Greffi Hoziyana .................................. 130

30. ROTAR PERTUAN (Roda Putar Persatuan Dan Kesatuan)

Usi Rochmawati ..................................................................... 133

31. MONDAI (Monopoli Pandai) Rahmatika Estiani ................ 137

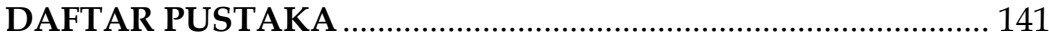




\section{BAGIAN I \\ KONSEP DASAR MEDIA \\ PEMBELAJARAN PKn}

\section{A. Pengertian Media Pembelajaran PKn}

Kata media berasal dari bahasa Latin medio? Dalam bahasa Latin, media dimaknai sebagai antara. Media merupakan bentuk jamak dari medium, yang secara harfiah berarti perantara atau pengantar. Sadiman (2012: 6) mengemukakan bahwa kata media berasal dari bahasa latin dan merupakan bentuk jamak dari kata medium yang secara harfiah berarti perantara atau pengantar. Secara khusus, kata tersebut dapat diartikan sebagai alat komunikasi yang digunakan untuk membawa informasi dari satu sumber kepada penerima. Dikaitkan dengan pembelajaran, media dimaknai sebagai alat komunikasi yang digunakan dalam proses pembelajaran untuk membawa informasi berupa materi ajar dari pengajar kepada peserta didik sehingga peserta didik menjadi lebih tertarik untuk mengikuti kegiatan pembelajaran. Dengan demikian media pembelajaran dapat dikatakan bahwa media merupakan wahana penyuluhan informasi belajar atau penyaluran pesan berupa materi ajar oleh guru kepada siswa sehingga siswa menjadi lebih tertarik dengan pembelajaran yang dilakukan.

Media dapat diartikan sebagai alat bantu untuk menunjang keberhasilan pembelajaran di kelas. Hal ini dapat dipertegas oleh Zainiyati (2013: 63) mengemukakan media pembelajaran adalah segala sesuatu yang dapat digunakan untuk menyalurkan pesan dari pengirim ke penerima sehingga merangsang pikiran, perasaan, perhatian dan minat serta kemauan siswa sedemikian rupa sehingga proses belajar terjadi dalam rangka mencapai tujuan pembelajaran secara efektif. Sedangkan definisi media pembelajaran menurut Yaumi (2018:7) mengemukakan media pembelajaran adalah semua bentuk peralat fisik yang didesain secara terencana untuk menyampaikan informasi dan membangun interaksi. Peralatan 
fisik yang dimaksud mencakup benda asli, bahan cetak, visual, audio, audio-visual, multimedia, dan web. Peralatan yang dirancang dan dikembangkan secara sengaja agar sesuai dengan kebutuhan siswa dan tujuan pembelajaran.

Berdasarkan penjelasan para ahli di atas, dapat disimpulkan bahwa media adalah alat bantu yang digunakan oleh guru dalam menyampaikan pesan berupa materi pelajaran kepada siswa agar siswa lebih mudah memahami tentang materi yang sedang di ajarkan. Satu hal yang perlu diingat bahwa peranan media tidak akan terlihat apabila penggunaannya tidak sejalan dengan isi dan tujuan pembelajaran yang telah dirumuskan. Secanggih apa pun media tersebut, tidak dapat dikatakan menunjang pembelajaran apabila keberadaannya menyimpang dari isi dan tujuan pembelajarannya. Sedangkan pengertian media PKn adalah media yang terpilih dan cocok untuk pembelajaran PKn SD.

\section{B. Fungsi Media Pembelajaran PKn SD}

Ada dua fungsi utama media pembelajaran yang perlu diketahui. Fungsi pertama media adalah sebagai alat bantu pembelajaran, dan fungsi kedua media adalah sebagai sumber belajar. Kedua fungsi utama tersebut dapat dijelaskan sebagai berikut:

1. Media pembelajaran sebagai alat bantu dalam pembelajaran

Bahwa setiap materi ajar memiliki tingkat kesukaran yang bervariasi. Pada satu sisi ada materi ajar yang tidak memerlukan alat bantu, tetapi di lain pihak ada materi ajar yang sangat memerlukan alat bantu berupa media pembelajaran. Media pembelajaran yang dimaksud antara lain berupa globe, grafik, gambar, dan sebagainya. Materi ajar dengan tingkat kesukaran yang tinggi tentu sukar dipahami oleh siswa. Tanpa bantuan media, maka materi ajar menjadi sukar dicerna dan dipahami oleh setiap siswa. Hal ini akan semakin terasa apabila materi ajar tersebut abstrak dan rumit/kompleks. 
Ada beberapa materi ajar bersifat rumit dan abstrak sehingga dalam penyampaian materi ajar mengalami kesulitan. Jika menemukan materi ajar yang bersifat abstrak maka dalam mejelaskan materi sebaiknya, sebaiknya menghadirkan media sebagai alat bantu pembelajaran guna mencapai tujuan yang telah ditetapkan. Sebagai alat bantu, media mempunyai fungsi melicinkan jalan menuju tercapainya tujuan pembelajaran. Hal ini dilandasi keyakinan bahwa kegiatan pembelajaran dengan bantuan media mempertinggi kualitas kegiatan belajar siswa dalam tenggang waktu yang cukup lama. Itu berarti, kegiatan belajar siswa dengan bantuan media akan menghasilkan proses dan hasil belajar yang lebih baik daripada tanpa bantuan media. Akhirnya, dapat dipahami bahwa media adalah alat bantu dalam kegiatan pembelajaran. Dalam hal ini, gurulah yang mempergunakannya untuk pembelajaran siswa demi tercapainya tujuan pembelajaran.

2. Media pembelajaran sebagai sumber belajar

Sumber belajar adalah segala sesuatu yang dapat dipergunakan sebagai tempat bahan pembelajaran untuk belajar peserta didik tersebut berasal. Sumber belajar dapat dikelompokkan menjadi lima kategori, yaitu manusia, buku perpustakaan, media massa, alam lingkungan, dan media pendidikan. Media pendidikan, sebagai salah satu sumber belajar, ikut membantu guru dalam memudahkan tercapainya pemahaman materi ajar oleh siswa, serta dapat memperkaya wawasan siswa.

Sudahkah mencoba menggunakan teknologi media ini dalam kegiatan pembelajaran? Jika belum, cobalah memanfaatkannya. Akan tetapi, jangan lupa untuk membekali diri terlebih dulu dengan segenap kemampuan dan keterampilan dalam mengoperasionalisasikannya, sehingga kegiatan pembelajaran yang dilakukan dapat berlangsung dengan lancar. 


\section{Peran Media Pembelajaran PKn SD}

Peran media sangat strategis dalam meningkatkan kualitas pembelajaran. Kemp dkk (1985) menjabarkan peran media di dalam kegiatan pembelajaran sebagai berikut:

1. Penyajian materi ajar menjadi lebih standar.

2. Penyusunan media yang terencana dan terstruktur dengan baik membantu pengajar untuk menyampaikan materi dengan kualitas dan kuatitas yang sama dari satu kelas ke kelas yang lain.

3. Kegiatan pembelajaran menjadi lebih menarik.

4. Kegiatan belajar dapat menjadi lebih interaktif.

5. Materi pembelajaran dapat dirancang, baik dari sisi pengorganisasian materi maupun cara penyajiannya yang melibatkan siswa, sehingga siswa menjadi lebih aktif di dalam kelas.

6. Media dapat mempersingkat penyajian materi pembelajaran yang kompleks, misalnya dengan bantuan video. Dengan demikian, informasi dapat disampaikan secara menyeluruh dan sistematis kepada siswa.

7. Kualitas belajar siswa dapat ditingkatkan. Penyajian pembelajaran dengan menggunakan media yang mengintegrasikan visualisasi dengan teks atau suara akan mampu mengkomunikasikan materi pembelajaran secara terorganisasi.

Dengan menggunakan media yang lebih bervariasi, maka siswa akan mampu belajar dengan lebih optimal. Dengan media yang makin lama makin canggih maka kegiatan pembelajaran tidak hanya dilakukan di dalam kelas saja tetapi dapat di mana saja. Misalnya, dengan teleconference pengajar dari luar kota dapat memberikan materinya, atau dengan CD peserta didik dapat mengikuti proses pembelajaran melalui media secara mandiri sesuai dengan kebutuhan mereka.

Masih banyak guru saat ini yang menganggap bahwa peran media dalam proses pembelajaran hanya terbatas sebagai alat bantu semata dan boleh diabaikan manakala media itu tidak tersedia di sekolah. Media pembelajaran merupakan 
salah satu komponen yang tidak berdiri sendiri, tetapi saling berhubungan dengan komponen lainnya dalam rangka menciptakan situasi belajar yang diharapkan. Tanpa media maka proses pembelajaran tidak akan berjalan dengan efektif.

Berikut ini secara lebih mendetail dijelaskan mengenai nilai-nilai yang dimiliki media pembelajaran dalam mengoptimalkan pencapaian hasil belajar. Nilai-nilai media pembelajaran diantaranya adalah sebagai berikut ini. Adapun manfaat itu adalah sebagai berikut:

1. Media pembelajaran dapat mengatasi keterbatasan pengalaman yang dimiliki oleh para siswa. Pengalaman tiap-tiap siswa berbeda, dari latar belakang kehidupan keluarga, lingkungan yang berbeda; maka anak akan mempunyai pengalaman yang berbeda. Ini disebabkan karena berbedanya "kesempatan untuk mengalami" yang diperoleh anak-anak, misalnya: adanya keterbatasan tersedianya buku, bacaan- bacaan, letak geografis, kesempatan berdarmawisata, dan lain-lain. Media pembelajaran dapat mengatasi perbedaan-perbedaan ini jika siswa tidak mungkin untuk dibawa ke objek yang dipelajari, maka objeklah yang dibawa ke siswa.

2. Mengkonkretkan konsep-konsep yang abstrak. Konsepkonsep yang dirasakan masih bersifat abstrak dan sulit dijelaskan secara langsung kepada siswa bisa dikonkretkan atau disederhanakan melalui pemanfaatan media pembelajaran. Misalnya untuk menjelaskan tentang sistem peredaran darah manusia, arus listrik, berhembusnya angin, dan sebagainya bisa menggunakan media gambar atau bagan sederhana.

3. Media pembelajaran dapat mengatasi keterbatasan indera, ruang, dan waktu. Banyak hal yang tidak mungkin dialami secara langsung di dalam kelas oleh siswa. Ini disebabkan oleh:

a. Objek terlalu besar, misalnya lingkungan pasar, terminal, stasiun, pelabuhan, candi, dan lain-lain. 
Dengan media seperti gambar, foto, slide, atau film, kita dapat menampilkannya ke hadapan siswa;

b. Menghadirkan objek-objek yang terlalu berbahaya atau sukar didapat ke dalam lingkungan belajar. Misalnya guru menjelaskan dengan menggunakan gambar atau program televisi tentang binatang-binatang buas, seperti harimau, beruang, gajah, jerapah, atau bahkan hewan-hewan yang sudah punah seperti dinosaurus, dan sebagainya;

c. Beberapa objek, makhluk hidup, dan gerakan-gerakan terlalu kecil untuk diamati dengan mata telanjang, misalnya: bakteri, sel darah, protozoa, dan lain-lain. Dengan bantuan gambar, film, dan mikroskop sebagai media pembelajaran dapat memperbesar dan memperjelas objek-objek tadi;

d. Gerakan-gerakan yang terlalu lambat untuk diamati seperti proses kepompong menjadi kupu-kupu dapat diikuti prosesnya dalam beberapa saat saja dengan teknik time-lapse dengan media fotographi, film, atau komputer;

e. Gerakan-gerakan yang terlalu cepat dan sulit ditangkap mata biasa, misalnya kepakan sayap burung, laju peluru, komet, dan lain-lain dapat diamati dengan media yang dapat memperlihatkan gerakan yang terlalu cepat, sehingga dengan menggunakan media film (slow motion) guru bisa memperlihatkan lintasan peluru, melesatnya anak panah, atau memperlihatkan proses suatu ledakan;

f. Ada kalanya objek yang akan dipelajari terlalu kompleks seperti peredaran darah atau siklus air hujan dapat ditampilkan dengan gambar, skema, atau simulasi komputer;

g. Bunyi-bunyi yang amat halus yang semula tidak mungkin ditangkap telinga menjadi jelas didengar dengan menggunakan media; 
h. Rintangan-rintangan untuk mempelajari musim, iklim, dan geografi secara umum dapat diatasi. Kehidupan ikan-ikan di dasar laut atau kehidupan gajah di hutan dapat dihadirkan di depan kelas melalui media;

i. Kejadian langka yang terjadi di masa lalu atau terjadi sekali dalam puluhan tahun dapat ditampilkan melalui rekaman video, film, foto, dan slide;

j. Kejadian atau percobaan yang dapat membahayakan dapat disimulasikan dengan media seperti komputer, film, dan video.

4. Media pembelajaran memungkinkan adanya interaksi langsung antara siswa dan lingkungannya.

5. Media menghasilkan keseragaman pengamatan. Persepsi yang dimiliki masing- masing siswa akan berbeda, apabila mereka hanya mendengar saja, belum pernah melihat sendiri bahkan pernah memegang, meraba, dan merasakannya. Untuk itu media dapat membantu memberikan persepsi yang sama, setelah dilakukan pengamatan yang dilakukan oleh siswa secara bersamasama dan diarahkan kepada hal-hal yang penting yang dimaksudkan oleh guru.

6. Media dapat menanamkan konsep dasar yang benar, konkret dan realistis. Sering kali sesuatu yang diterangkan oleh guru diterima sebagai konsepsi yang berbeda oleh siswa yang berbeda pula. Penggunaan media seperti gambar, film, objek, model, grafik, dan lain-lain bisa memberikan konsep dasar yang benar.

7. Media membangkitkan motivasi dan rangsangan anak untuk belajar. Pemasangan gambar-gambar di papan tempel, pemutaran film, mendengarkan rekaman atau radio merupakan rangsangan-rangsangan tertentu ke arah keinginan untuk belajar.

8. Media membangkitkan keinginan dan minat guru. Dengan menggunakan media pembelajaran, horizon pengalaman anak semakin luas, persepsi semakin tajam, konsep-konsep 
dengan sendirinya semakin lengkap. Akibatnya keinginan dan minat untuk belajar selalu muncul.

9. Media memberikan pengalaman yang integral atau menyeluruh dari konkret sampai hal yang bersifat abstrak. Sebuah film Candi Borobudur misalnya, dapat memberikan imaji yang konkret tentang wujud, ukuran, lokasi candi, dan sebagainya.

\section{Manfaat Media Pembelajaran PKn SD}

Keberadaan media dalam proses pembelajaran tentu saja akan memberikan banyak manfaat terutama bila media tersebut digunakan sesuai dengan kondisi yang ada. Dalam Encyclopedia of Educational Reasearch yang dikutip oleh Oemar Hamalik (1986:3) bahwa manfaat media pendidikan yaitu:

1. Meletakkan dasar-dasar yang konkrit untuk berpikir, oleh karena itu mengurangi "Verbalisme"

2. Memperbesar perhatian siswa

3. Meletakkan dasar-dasar yang penting untuk perkembangan belajar oleh karena itu membuat pelajaran lebih mantap

4. Memeberikan pengalaman yang nyata yang dapat menumbuhkan kegiatan berusaha sendiri dikalangan siswa

5. Menumbuhkan pemikiran yang teratur dan kontinu, hal ini terutama terdapat daam gambar hidup.

6. Membantu tumbuhnya pemikiran dengan demikian membantu perkembangan kemampuan berbahasa

7. Memberikan pengalaman-pengalaman yang tidak mudah diperoleh dengan cara lain serta membantu berkembangnya efisisensi yang lebih mendalam yang lebih banyak dalam belajar

Manfaat dari media juga diungkapkan oleh Nana Sudjana, dkk. (2002:2) yang mengungkapkan manfaat media dalam proses belajar siswa antara lain:

1. Pengajaran akan lebih menarik perhatian siswa sehingga dapat menumbuhkan motivasi belajar; 
2. Bahan pengajaran akan lebih jelas maknanya sehingga dapat lebih diapahami oleh para siswa, dan memungkinkan siswa menguasai tujuan pengajaran yang lebih baik;

3. Metode mengajar akan lebih bervariasi, tidak semata-mata komunikasi verbal melalui penuturan kata-kata oleh guru, sehingga siswa tidak bosan dan gurunya tidak kehabisan tenaga, apalagi guru mengajar untuk setiap pelajaran;

4. Siswa lebih banyak melakukan kegiatan belajar, sebab tidak hanya mendengarkan uraian guru tetapi juga aktivitas lain seperti mendemonstrasikan, mengamati, melakukan, dll.

5. Dari berbagai pendapat ahli tersebut dapat disimpulkan bahwa manfaat media pembelajaran adalah untuk membantu siswa maupun guru dalam kegiatan belajar mengajar, sehingga guru dapat dengan mudah menjelaskan materi pelajaran kepada siswa, begitu pula dengan siswa mereka akan lebih mudah memehami materi pelajaran yang diberikan oleh guru. Media juga dapat memberikan kesempatan pada siswa untuk dapat belajar mandiri tanpa adanya kehadiran guru.

\section{E. Rancangan Media Pembelajaran PKn Sekolah Dasar}

Mata pelajaran PKn mempunyai misi membina nilai, moral, dan norma secara utuh bulat dan berkesinambungan. Tujuan PKn adalah untuk membentuk watak warga negara yang baik, yaitu yang tahu, mau dan sadar akan hak dan kewajibannya. Pada pedoman Belajar Mengajar Sekolah Dasar Kurikulum 2006, PKn memiliki karakter yang berbeda dengan matapelajaran lainnya. Hal ini dapat dilihat berdasarkan ciriciri atau hal-hal yang bersifat khusus, yang pada prinsipnya PKn lebih menekankan pada pembentukan aspek moral (afektif) tanpa meninggalkan aspek yang lain. Untuk mencapai sasaran dan target tersebut, dalam pelaksanaan pembelajaran diperlukan penataan alat, bahan, dan sumber belajar agar dapat dilihat dan mudah digunakan oleh siswa. Sumber belajar dapat berupa media cetak, model, gambar-gambar, laporan, dan 
kliping. Media pembelajaran dalam PKn harus dapat menstimulus lahirnya proses pembelajaran yang aktif dan kreaktif. Dalam pedoman pelaksanaan kegiatan belajar mengajar PKn SD, ada beberapa syarat yang harus diperhatikan untuk media PKn, yaitu:

1. membawakan sesuatu atau sejumlah isi pesan harapan

2. memuat nilai atau moral kontras

3. diambil dari dunia kehidupan nyata

4. menarik minat dan perhatian siswa

5. terjangkau oleh kemampuan belajar siswa

Merancang media pembelajaran PKn sangat tergantung dari jenis media yang digunakan. Di bawah ini diulas kembali jenis media yang dapat digunakan/dikembangkan dalam pembelajaran PKn, yaitu:

1. hal-hal yang bersifat visual, seperti bagan, matriks, gambar, data, dan lain-lain

2. hal-hal yang bersifat materiil, seperti model-model, benda contoh

3. gerak, sikap, dan perilaku, seperti simulasi, bermain peran, role playing

4. cerita, kasus yang mengundang dilema moral,dll.

Ada beberapa pedoman umum yang perlu diperhatikan dalam penggunaan media dalam proses pembelajaran.

1. Tidak ada satu media yang terbaik untuk mencapai suatu tujuan pembelajaran, karena masing-masing memiliki kelebihan dan kekurangan.

2. Penggunaan media harus didasarkan pada tujuan pembelajaran yang hendak dicapai.

3. Penggunaan media harus mempertimbangkan kecocokan ciri media dengan karakteristik materi pelajaranyang disajikan.

4. Penggunaan media harus disesuaikan dengan bentuk kegiatan belajar yang akan dilaksanakan, seperti belajar secara klasikal, belajar dalam kelompok kecil, belajar secara individual. 
5. Penggunaan media harus disertai persiapan yang cukup, seperti mengecek media yang akan dipakai, mempersiapkan serbagai peralatan yang dibutuhkan di ruang kelas sebelum pengajaran di mulai.

6. Siswa perlu disiapkan sebelum media pembelajaran digunakan agar mereka dapat mengarahkan perhatian pada hal-hal yang penting selama penggunaan media.

7. Penggunaan media harus diusahakan agar senantiasa melibatkan partisipasi aktif para siswa. 


\section{BAGIAN II \\ CONTOH-CONTOH MEDIA PEMBELAJARAN PKn SD}




\section{1.}

\section{MEDIA PEMBELAJARAN PKn}

KANTONG PENGETAHUAN

Oleh : Titis Dias Restanti

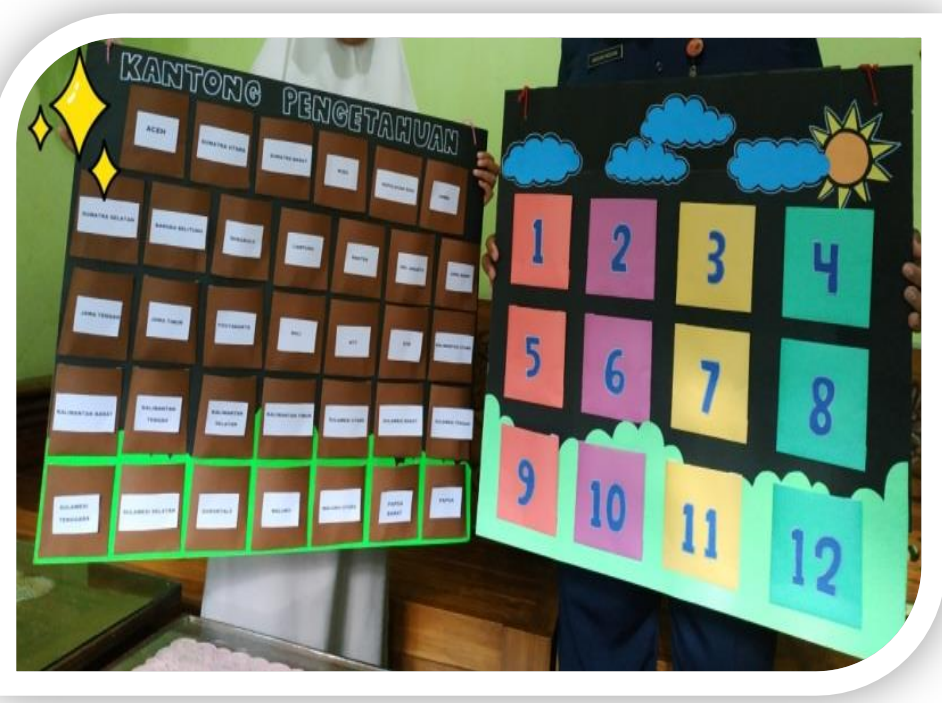

A. Deskripsi Media Pembelajaran Kantong Pengetahuan

Kantong Pengetahuan adalah media pembelajaran Pkn yang digunakan untuk memudahkan siswa dalam belajar keberagaman sosial budaya indonesia dengan mudah dan tidak membosankan karena dilakukan sambil bermain karena belajar mengenai keberagaman sosial budaya tidak hanya dibuku melainkan bisa dengan menggunakan media yang anak akan mendapat pengalaman belajar yang berbeda karena menggunakan media kantong pengetahuan. Media ini berukuran sebesar kertas karton. Media ini berisikan gambar didalam kantong dan kantong daerah. Media ini juga dapat membantu guru dalam menyampaikan pesan atau materi yang diajarkan. 
1. Materi Pembelajaran

Keberagaman Sosial Budaya Masyarakat

2. Bahan dan Alat yang diperlukan

1. Bahan
a. Kertas Karton
b. Kertas Origami
c. Kertas Asturo
d. Kertas manila
e. Gambar - gambar rumah adat, tarian daerah dan tulisan nama - nama provinsi

2. Alat
a. Gunting
b. Tali
c. Spidol Putih dan Double Tip

\section{B. Langkah-Langkah Pembuatan Media Pembelajaran Kantong Pengetahuan}

1. Siapkan kertas karton, kertas manila dan kertas asturo

2. Tempel kertas manila kekertas karton

3. Kemudian buat hiasan seperti rumput dan tempelkan ke kertas karton yang sudah ditempel kertas manila.

4. Lipat kertas origami menjadi kantong kotak sebanyak 12

5. Tempelkan kertas origami yang sudah dibuat kantong ke kertas karton yang sudah ditempel kertas manila.

6. Beri angka pada kotak yang sudah ditempel

7. Gunting kartu gambar gambar rumah adat dan tarian daerah serta nama - nama provinsi

8. Siapkan kertas karton kemudian tempel dengan kertas manila

9. Kemudian lipat kertas asturo yang sudah dipotong menjadi kantong kotak sebanyak 34 lalu tempel pada kertas karton yang sudah di tempel kertas manila.

10. Tempel nama - nama provinsi yang sudah digunting ke kantong yang jumlahnya 34

11. Beri lubang di bagian atas kanan dan kiri pojok pada kedua kertas karton tersebut kemudian beri tali. 


\section{Penerapan Media Pembelajaran Kantong Pengetahuan dalam Pembelajaran}

1. Pembelajaran dimulai dengan berdoa.

2. Sebelum menggunakan media, guru menjelaskan terlebih dahulu materi keberagaman sosial budaya.

3. Setelah menjelaskan materi, kemudian guru menyiapkan media yang akan digunakan.

4. Guru menaruh media didepan kelas, kemudian guru menjelaskan cara pemakaian dari media kantong pengetahuan.

5. Media ini pemakaiannya dengan digantung didepan kelas atau diletakan di kursi.

6. Siswa diminta maju dan mengambil kartu di kantong yang bertuliskan angka, kemudian mengambil gambar yang ada dikantong sesuai dengan angka yang dipilih.

7. Selanjutnya siswa diminta mengidentifikasi gambar tersebut berasal dari daerah mana.

8. Setelah terjawab siswa memasukan gambar tersebut pada kantong sesuai dengan daerah dari gambar tersebut, dan siswa dapat kembali ke bangku masing - masing.

9. Setelah itu guru menjelaskan kembali

10. Siswa dapat memahami keberagaman sosial budaya masyarakat dengan bermain dan memudahkan siswa untuk belajar dan mangingat dengan baik. 